\title{
ELEMENTAL ANALYSIS OF OLD MORTAR USED IN VARIOUS ARCHAEOLOGICAL SITES OF BANGLADESH BY SEM AND EDAX
}

\author{
ACHIA KHANOM ${ }^{1}$, D. K. SAHA ${ }^{2}$, S. M. RAHAMAN ${ }^{1}$ AND AL MAMUN ${ }^{2}$ \\ ${ }^{I}$ Department of Archaeology, Jahangirnagar University, Savar, Dhaka \\ ${ }^{2}$ Materials Science Division, Atomic Energy Centre, Dhaka-1000
}

\begin{abstract}
Morphological characterization and mineralogical studies were performed on fifteen mortar samples collected from three ancient archaeological sites (Wari-Bateshwar, Lalmai-Mainamati, and Paharpur) of Bangladesh. Many cracks and pores were found in the mortar samples of Buddhist Lotus temple of Wari-Bateshwar. Energy dispersive analytical X-ray analysis confirmed the presence of $\mathrm{C}, \mathrm{O}, \mathrm{P}, \mathrm{K}, \mathrm{Al}, \mathrm{Fe}, \mathrm{Na}, \mathrm{Mg}, \mathrm{Mn}, \mathrm{Si}$ and $\mathrm{Ti}$ in the mortar samples. The absence of $\mathrm{Ca}$ in the samples indicates that the clay was used in the architecture as binding materials. In the clay mortar, Si played an important role and with the presence of $\mathrm{O}_{2}, \mathrm{SiO}_{2}$ was formed, which strengthened the binder. $\mathrm{K}, \mathrm{Al}, \mathrm{Fe}, \mathrm{Na}, \mathrm{Mg}, \mathrm{Mn}, \mathrm{Si}$ and Ti might form compounds like $\mathrm{SiO}_{2}, \mathrm{Fe}_{2} \mathrm{O}_{3}, \mathrm{~K}_{2} \mathrm{O}$, $\mathrm{Al}_{2} \mathrm{O}_{3}, \mathrm{MgO}, \mathrm{MnO}, \mathrm{Na}_{2} \mathrm{O}_{3}$, and $\mathrm{TiO}_{2}$ with $\mathrm{O}_{2}$. The oxidation of $\mathrm{Fe}^{+2}$ produced $\mathrm{Fe}_{2} \mathrm{O}_{3}$ which was responsible for breaking down the bonding of mortars.
\end{abstract}

Key words: Archaeology, Mortar, Deterioration, SEM and EDAX

\section{Introduction}

Mortar analysis is an essential domain for conservation of architectural remains of Bangladesh. Mortar, a workable paste, generally formed by the mixture of cement, sand and water, is a fine aggregate to fill the gaps between construction bricks and stones. Aziz (1995) classified the types of mortar as follows (i) mud mortar (ii) lime mortar (iii) surki mortar (iv) lime surki mortar and (v) cement mortar. In the world context, the mud mortar was made from the mud clay. In early Egyptian time (2600-2500 B.C.), pyramids were constructed using limestone blocks that were bound either by mud and clay or clay and sand mortar. Later on, a different mortar was used for constructing Egyptian pyramid which was made of either gypsum or lime. The lime mortar was used in ancient Egypt before 4000 B.C. (Wikipedia 01-07-2012). Different types of mortar have been used in masonry building construction since ancient to date in Bangladesh. Present research is to focus on elemental analysis of old mortar used in various archaeological sites (WariBateshwar, Lalmai-Mainamati, and Paharpur) of Bangladesh.

\section{Brief history of the study sites}

Wari-Bateshwar (5 $5^{\text {th }}$ Century B.C.): Wari-Bateshwar is an important early historic archaeological site of Bangladesh located at Belabo Upazila in Narsingdi. The two

\footnotetext{
${ }^{1}$ Corresponding author: Email: likhon000@yahoo.com
} 
thousand five hundred years old fort-city stands on the bank of the river Brahamhaputra. In recent research, it is assumed that Wari-Bateshwar was the ancient trade centre named 'Sounagara' as mentioned by the Greek geographer Ptolemy (Rahman 2001). Among the 48 archaeological sites discovered in Wari-Bateshwar region, Wari is configured as the nucleus of the sites. During excavation (2000-2009), a unique brick architecture with dimension $18 \mathrm{~m} \times 32 \mathrm{~m}$ was discovered (Photo 1).

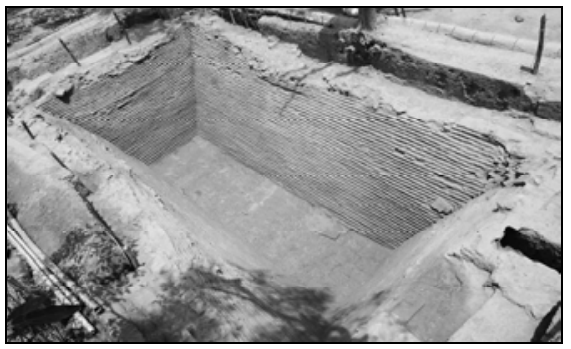

Photo 1. Unique brick architecture at WariBateshwar.

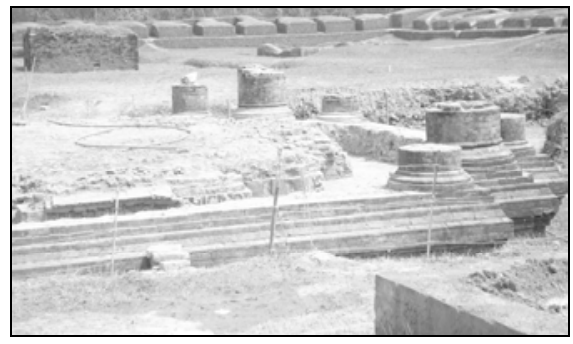

Photo 2. Small cruciform temple at Salban Vihara.

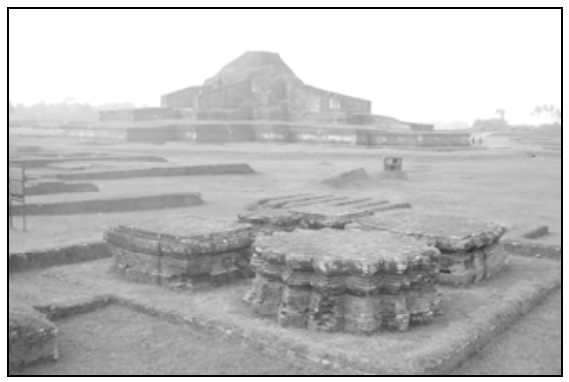

Photo 3. Paharpur main temple at Naogaon.

Lalmai-Mainamati $\left(6^{\text {th }}\right.$ to $13^{\text {th }}$ centuries A.D.): Lalmai-Mainamati was one of the attractive places for the Buddhist community. Rashid (1997) reported that it was the second largest city of ancient Bangladesh in which the religious establishment, together with large Viharas and the constituent's colleges of the Buddhist University, were built. Hossain (2007), Ahmed (1975) and Rashid (1997) reported that huge collection of artifacts, large number of stupa and monastery indicate that the site was flourished from $7^{\text {th }}$ to $13^{\text {th }}$ centuries A.D. Ali and Alam (2000) and Rashid (1997) reported that some structural remains have been discovered by excavation at Lalmai-Mainamati from 1955 to 2000. These are Salban Vihara, Kutila Mura, Charpatra Mura, Rupban Mura, Itakhola Mura, Anada Vihara, Bhoja Vihara, Lati coat Mura, and Queen Mainamtai's palace mound. During (2008-2009) excavation, a small cruciform temple (Photo 2) and stupa near to Salban Vihara were discovered. 
Paharpur ( $8^{\text {th }}$ to $13^{\text {th }}$ centuries A.D.): The archaeological remains of Paharpur (World Cultural Heritage Site) represent the most spectacular and magnificent monument of Bangladesh. It is the second largest Buddhist monastery situated at the South of the Himalayas. It is also known as Somapura Mahavihara (Photo 3). Excavation at Paharpur was carried out by G.C. Chandra during 1925-26, 1930-32 and Dikshit in 1928-29 and 1934 under the supervision of Archaeological Survey of India (ASI). A report on Paharpur archaeological excavation was published by Dikshit in 1938. Alam (2004) reported that, with the help of UNESCO, the Department of Archaeology skillfully excavated the site in 1981-82, 1984-85, 1988-89 and 1990-91 and three major building phases in the monastic cells were established. Rectangular monastery with 177 cells and Varanda, a cruciform temple, different types of stupa, viz. star shape, octagonal, square, and votive stupas are the main features of Paharpur archaeological site.

Literature Review: Mortar analysis is a multidisciplinary task (Patricia et al. 2008). Most of the modern European researchers like Bentz and Momber (2002 and 2003), Valckenborg et al. (2001), Brocken et al. (2006), Válek (1995), Rijniers (2004), and Petkovic (2005) discussed mainly on the use of mortar from the $14^{\text {th }}$ to $20^{\text {th }}$ centuries. They have focused on the characterization, mineralogical study, elemental analysis, composition, micro crystal structure, chemical analysis, particle size, process of cracks extension, porosity, mass and aging of mortars, by using different scientific methods such as XRD (X-Ray Diffractometer), SEM (Scanning Electron Microscopy), XRF (XRay Fluorescence), IR (IR-Infra-red) Spectroscopy, NMR (Nuclear Magnetic Resonance) Spectroscopy, Mass Spectroscopy, Atomic absorption Spectroscopy, TGA (Thermogravimethic Analysis), $\mathrm{pH}$, conductivity, chemical analysis and ${ }^{14} \mathrm{C}$ dating. Patricia et al., (2008) have analyzed mortar from southern Portugal cathedrals (Evora e Elvas) by optical microscopy and XRD. They found that quartz, feldspar, mica, amphiboles and calcite minerals are present in the mortars. Habesch (2006) studied the biofilm (fungi and algae) distribution on mortar surfaces by SEM and EDAX. Mortar compounds such as quartz and lime were detected. Rapp (2002, 2003 and 2009) reported in his book 'Archaeomineralogy'about the aggregate used in ancient mortar. Velosa et al. (2007) studied various samples at archaeological site of Conímbriga and determined particle size distribution, execution and visualization of thin sections by thermal analysis, mineralogical and chemical analysis using XRD and XRF. The results indicate that the crushed ceramic particle was used as raw materials in the mortar. Ellis (2002) studied the morphological, textural and compositional interrelationships of mortar by SEM and elemental analysis by EDAX, and reported history of lime mortars, specification of mortars and characteristics of various lime mortars. Jordan et al. (2006) have studied mortars from the wall of cattle tank in Newcastle where $\mathrm{K}, \mathrm{Al}, \mathrm{Ca}, \mathrm{Fe}, \mathrm{Na}, \mathrm{Mg}$, and $\mathrm{Si}$ were determined by SEM. They have found $\mathrm{SiO}_{2}$ and $\mathrm{CaCO}_{3}$ in the samples by XRD analysis. Akasheh et al. (2003-05) studied mortars from Archaeological Sites at Petra of Mediterranean area by FTIR and XRD analysis. They found calcite, dolomite, kaolinite, 
montmorillonite, quartz, and micrite minerals. $\mathrm{Fe}_{2} \mathrm{O}_{3}, \mathrm{MnO}, \mathrm{TiO}_{2}, \mathrm{CaO}, \mathrm{K}_{2} \mathrm{O}, \mathrm{P}_{2} \mathrm{O}_{5}$, $\mathrm{SiO}_{2}, \mathrm{Al}_{2} \mathrm{O}_{3}, \mathrm{MgO}$ and $\mathrm{Na}_{2} \mathrm{O}_{3}$ were determined by XRF. Candeias et al. mainly discussed the methodology for characterization of ancient mortars from different author results. Porosity and cracks were determined by optical microscope. Salts, pozzolanic products or organic/biological microorganisms were determined by SEM.

In a previous study (Khanom 2007) the terracotta plaque of Paharpur with mortar were analysed by XRD and it was found that the terracotta contains montmorillonite, chlorite, illite, kaolinite, attapulgite, quartz, feldspar, albite and calcite. $\mathrm{SO}_{4}{ }^{2-}$ and $\mathrm{Cl}^{-}$ion were found in the restored mortar sample of Paharpur by chemical analyses. Islam (2005) analyzed mortar from Shait Gambuz Mosque and found $\mathrm{CaO}(85.60 \%), \mathrm{SiO}_{2}(5.90 \%)$, $\mathrm{Al}_{2} \mathrm{O}_{3}(5.00 \%), \mathrm{Fe}_{2} \mathrm{O}_{3}(3.10 \%)$ by chemical analysis. Masud et al. (2008) studied mineralogy of archaeological soil of Paharpur by XRD and quartz, K-feldspar, Cafeldspar, kaolinite, illite and chlorite were determined in the soil samples. It is, therefore of interest to study elemental concentration of mortar by EDAX and morphological study by SEM to determine crack and pore of mortar samples.

\section{Materials and Methods}

Fifteen mortar samples were collected from the joint areas of brick masonry wall of Wari-Bateshwar, Lalmai-Mainamati, and Paharpur to investigate the morphological characteristic and elemental concentration of mortar. The collected mortar samples were cleaned followed by laboratory test. Solid samples were cleaned by white sprit. The pellets of samples were prepared in $50 \mathrm{~mm}$ dia. and $3 \mathrm{~mm}$ thick size for SEM and EDAX analyses. Surface of the pellet was polished by emary paper. Pellet was cleaned by white sprit for removal of dust particles.

SEM and EDAX study: In the present study SEM was used to determine the surface morphology of the mortars, specially cracks and pores of the samples. EDAX was used to unveil the elemental composition of mortars. Pellet samples were fitted into the sample chamber and scan the pellets with electron beam. Energy dispersive X-ray method was used for elemental analysis of mortar samples. High resolution FEI S50 scanning electron microscope was used. SEM images were taken in secondary electron scanning mode using $25 \mathrm{KV}$ accelerating voltage. Images were taken with the magnification of $100000 \mathrm{X}$ and the resolution of 50 to $100 \mathrm{~nm}$ in secondary electron scanning mode.

\section{Results and Discussion}

Morphological study of Mortar: In the present study, it was observed that surface of the mortar was rough. A large number of cracks were found in the samples of WBBLT 1 \& 4. Big size pores were found $(20 \mu \mathrm{m})$ in the samples of WBBLT-4 which indicate weakening of the joint areas. Small sizes of pores and cracks were found $(1 \mu \mathrm{m})$ in the 
sample of LM-2, and PPMT-1, which indicates strengthening of the joint areas of these sites (Fig. $1(\mathrm{a}, \mathrm{b})$. A few number of pores were found in the samples of LM-2 and PPMT-1 which indicates that the joint area is stable of these sites (Fig.1 c, d). It is understandable that the cracks and pores are responsible for the deterioration of mortar strength in different locations of these sites. Pore is one of the physical criteria which enhancing deterioration of mortars as well as brick masonry walls.

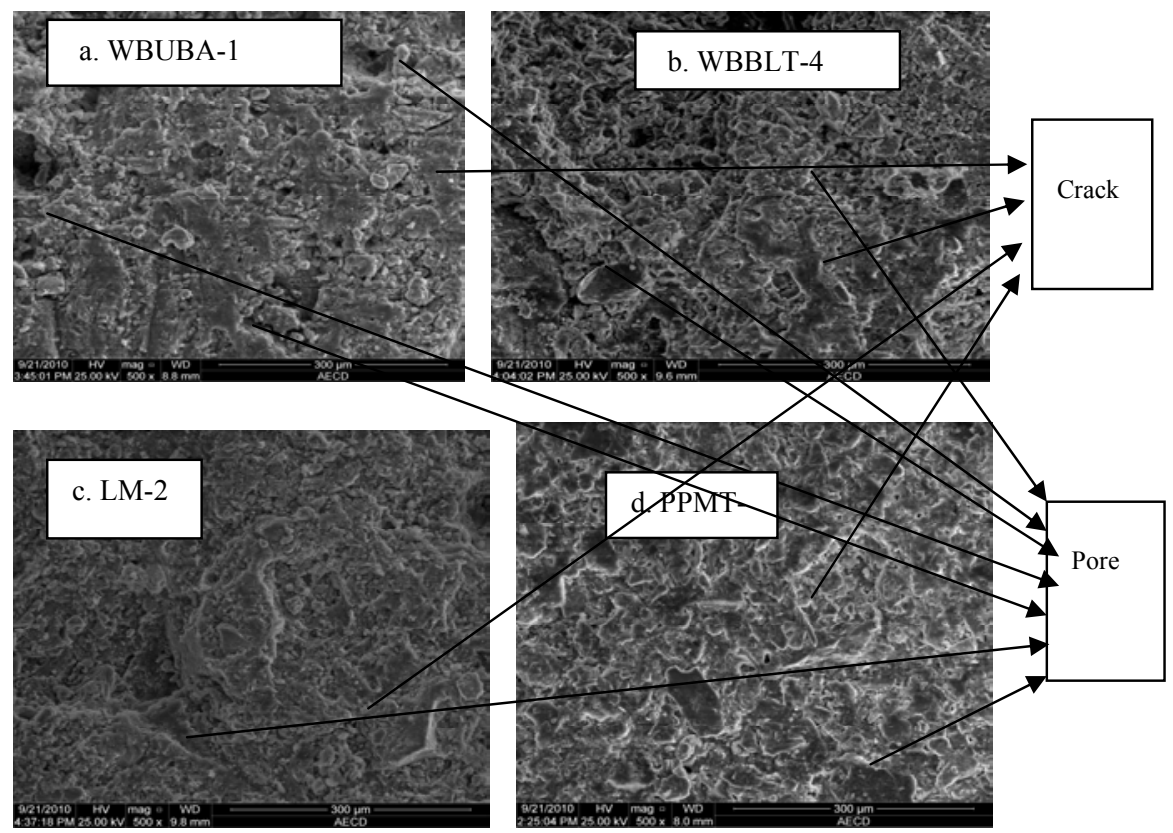

Fig.1. SEM images showing cracks and pores of mortar samples: a. WBUBA-1, b. WBBLT-4, c. LM-2 and d. PPMT-1.

Deteriorating agents like wind, dust and dirt, rainwater, ground water, flood water, atmospheric gases, acidic ion, salt, and plant-roots can easily enter into the mortars through the pores and cracks. Large number of pores and cracks are helpful for intruding rainwater, air and ions inside the mortars, which played significant role for the deterioration of mortars. These were observed in the West wall of Buddhist Lotus Temple in Wari-Bateshwar. Small sizes pores were found in the samples of newly discovered "Small Cruciform Temple" near the Salban Vihara at Lalmai-Mainamati. Hence, stability of mortar was found well in Lalmai-Mainamati sites leading to less damage of the architectural remains of these sites.

Elemental analysis of mortar: Representative examples of elemental spectrum of mortar samples, where the following elements have been found: C, O, P, K, Al, Fe, Na, Mg, Mn, 
$\mathrm{Si}$, and Ti are presented in Fig. 2(a-d). Each element has its individual energy for its $\mathrm{K}_{\alpha}$ and $\mathrm{K}_{\beta}$ shells. In Fig. 2 individual elements are shown with their corresponding $\mathrm{K}_{\alpha}$ and $\mathrm{K}_{\beta}$ energy level. Energy level of each element is shown in the parenthesis. $\mathrm{K}$, $\mathrm{Ti}$ and $\mathrm{Fe}$ show two peaks, $\mathrm{K}_{\alpha}$ and $\mathrm{K}_{\beta}$. The Multi Channel Analyzer (MCA) was calibrated using known standards and then the corresponding energy level was detected for each element. For each element corresponding counts was used to calculate the concentration by comparing the counts of standard of same element. Counts of all the overlapping peaks $\left(\mathrm{K}_{\alpha}\right.$ and $\mathrm{K}_{\beta}$ ) were separated by using $\mathrm{K}_{\beta} / \mathrm{K}_{\alpha}$ ratio.
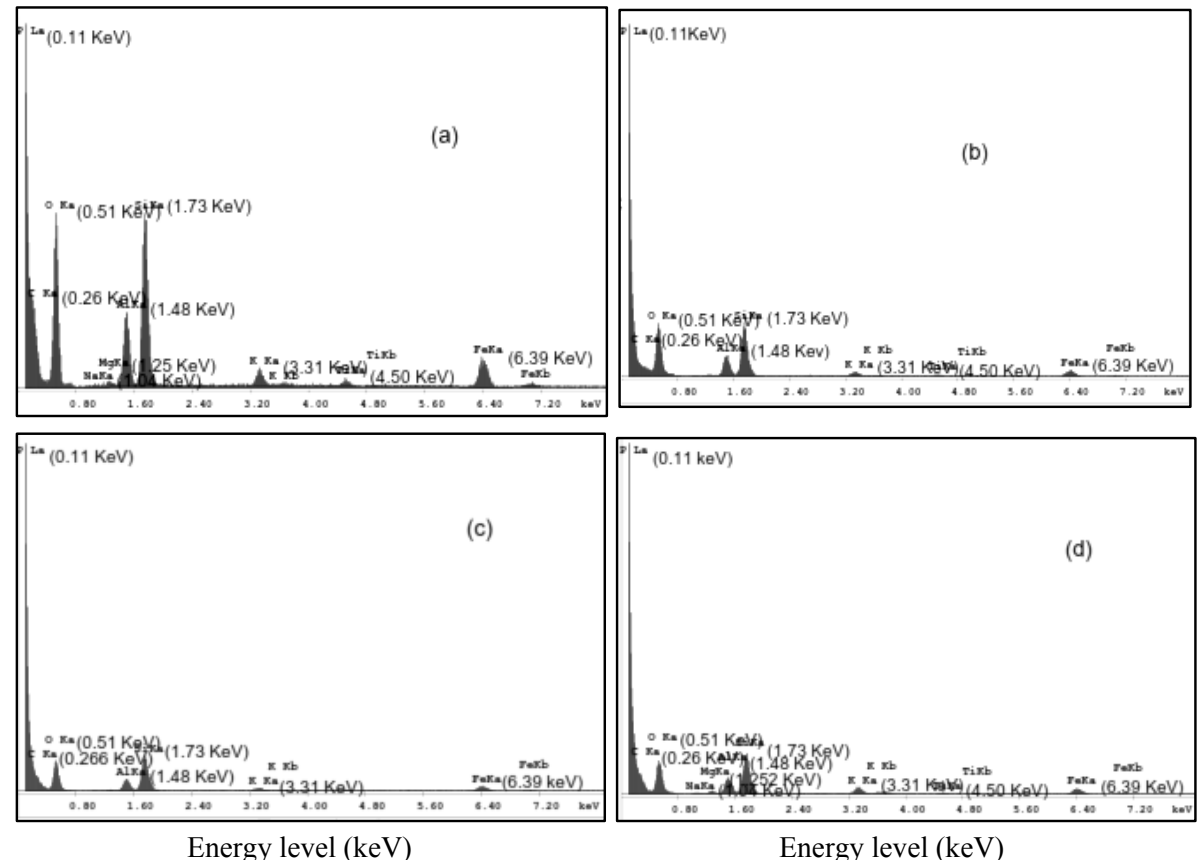

Energy level (keV)

Energy level $(\mathrm{keV})$

Fig. 2. EDAX spectrum showing various elements of mortar sample: (a). WBUBA-1, (b). LM-1, (c). LM-2 and (d). PPMT-1.

Elemental concentrations of $\mathrm{C}, \mathrm{O}, \mathrm{P}, \mathrm{K}, \mathrm{Al}, \mathrm{Fe}, \mathrm{Na}, \mathrm{Mg}, \mathrm{Mn}, \mathrm{Si}$, and $\mathrm{Ti}$ have been determined and listed in Table 1. The principal constituent was found as Si. Higher rates of $\mathrm{O}_{2}$ (21.98 to $\left.35.80 \mathrm{wt.} \%\right)$ and $\mathrm{Si}(13.52$ to $25.16 \mathrm{wt} . \%)$ have been found in all the mortar samples which might come from $\mathrm{SiO}_{2}$. Higher amounts of $\mathrm{O}_{2}(35.80$ wt.\%) and $\mathrm{Fe}$ (20.94 wt.\%) have been found in the mortar samples of PPMT-2 which indicate weakening the joint areas at Paharpur main temple. Less amount of $\mathrm{Al}$ (5.06 to11.10 wt.\%), K(1.98 to 6.98 wt.\%) and $\mathrm{Mg} 0.44$ to $2.12 \mathrm{wt.} \%$ have been found in most of the samples. $1.6 \mathrm{wt} . \%$ of Mn has been found in the sample of WBBLT-4. Quartz is the most stable of all minerals in the earth surface environment (Rapp et al. 1930). Higher amount of $\mathrm{Si}$ and $\mathrm{O}_{2}$ might come from sand. The study indicates that clay with sand has been 
used as mortar. The presence of Si in the samples of WBUBA-1-3, WBBLT-4-5, LM-1 to LM-5, and PPMT-1 to PPMT-5, indicates that silicate played significant role for the architecture of these sites. Si is durable because it has high ability to preserve water and release of water easily. Si played significant role as strong element.

Table1. Elemental concentration of mortar samples in wt. \%.

\begin{tabular}{llllllllll}
\hline Sample ID & $\mathrm{Al}$ & $\mathrm{C}$ & $\mathrm{Fe}$ & $\mathrm{K}$ & $\mathrm{Mg}$ & $\mathrm{Na}$ & $\mathrm{O}$ & $\mathrm{Si}$ & $\mathrm{Ti}$ \\
\hline WBUBA-1 & 6.61 & 24.56 & 19.86 & 2.77 & 0.56 & 0.31 & 27.53 & 16.09 & - \\
WBUBA-2 & 5.51 & 25.66 & 18.97 & 2.66 & 0.66 & - & 28.89 & 15.05 & - \\
WBUBA-3 & 6.09 & 24.78 & 19.56 & 2.46 & 0.56 & - & 27.93 & 16.09 & - \\
WBBLT-4 & 5.38 & 28.89 & 14.59 & 1.98 & 0.58 & - & 28.72 & 16.94 & 1.31 \\
WBBLT-5 & 6.27 & 26.75 & 17.25 & 2.21 & 0.44 & - & 29.12 & 16.21 & 1.04 \\
LM-1 & 6.44 & 26.31 & 14.74 & 2.47 & - & - & 31.34 & 16.96 & 1.74 \\
LM-2 & 4.74 & 35.83 & 15.99 & 2.40 & - & - & 25.71 & 15.33 & - \\
LM-3 & 6.99 & 25.23 & 17.26 & 2.70 & 0.54 & 0.29 & 28.78 & 16.56 & 1.60 \\
LM-4 & 5.28 & 29.16 & 16.50 & 2.40 & 0.44 & 0.24 & 30.62 & 15.65 & 1.45 \\
LM-5 & 6.71 & 27.56 & 15.87 & 2.44 & 0.56 & 0.51 & 29.98 & 16.75 & 1.56 \\
PPMT-1 & 5.06 & 36.55 & 14.57 & 3.98 & 0.99 & 0.51 & 23.42 & 13.52 & 1.39 \\
PPMT-2 & 11.10 & - & 20.94 & 6.98 & 2.12 & - & 35.80 & 23.06 & - \\
PPMT-3 & 7.76 & 30.21 & 14.91 & 3.98 & 2.05 & - & 29.85 & 25.16 & - \\
PPMT-4 & 6.54 & 35.76 & 18.94 & 5.16 & 2.12 & - & 31.94 & 22.78 & - \\
PPMT-5 & 5.17 & 36.12 & 20.16 & 4.71 & 2.04 & - & 35.12 & 24.72 & - \\
\hline
\end{tabular}

On the other hand, elements like $\mathrm{Na}$ and $\mathrm{Fe}$ can assist retention of moisture and water easily and can deteriorate mortar faster than Si. Jordan et al. (2006) reported that Al and Fe would come from the clay content of the mixing sand. Presence of $\mathrm{Al}$ and $\mathrm{Fe}$ in the samples of WBUBA-1-3, WBBLT-4-5, LM-1 to LM-5, and PPMT-1 to PPMT-5 indicate that clay with sand was used as mortar component for the architecture. $\mathrm{Mg}$ and $\mathrm{K}$ are likely to be minor constituents of the shells and or the sand (Jordan et al. 2006). Presence of $\mathrm{Mg}$ and $\mathrm{K}$ in the samples of Paharpur, and Wari-Bateshwar suggest that clay with sand were used as mortar component. K, Al, Fe, $\mathrm{Na}, \mathrm{Mg}, \mathrm{Mn}$, Si and Ti might formed $\mathrm{SiO}_{2}$, $\mathrm{Fe}_{2} \mathrm{O}_{3}, \mathrm{~K}_{2} \mathrm{O}, \mathrm{Al}_{2} \mathrm{O}_{3}, \mathrm{MgO}, \mathrm{MnO}, \mathrm{Na}_{2} \mathrm{O}_{3}$, and $\mathrm{TiO}_{2}$ compounds with $\mathrm{O}_{2}$. Among these compounds $\mathrm{SiO}_{2}$ played significant role for longevity of brick masonry. $\mathrm{SO}_{4}{ }^{2-}$ and $\mathrm{Cl}^{-}$ have been found from the wet chemical analysis and $\mathrm{Ca}, \mathrm{Na}, \mathrm{Mg}, \mathrm{K}, \mathrm{O}, \mathrm{P}, \mathrm{Al}, \mathrm{Mn}, \mathrm{Si}, \mathrm{Fe}$, and Ti have been found from the EDAX analysis. There might be formation of $\mathrm{MgSO}_{4}$, $\mathrm{NaCl}, \mathrm{FeSO}_{4}, \mathrm{Al}_{2}\left(\mathrm{SO}_{4}\right)_{3}, \mathrm{KCl}, \mathrm{CaSO}_{4}$ salt, which are responsible for breaking down the mortars (Khanom 2012). Oxidation of $\mathrm{Fe}^{+2}$ produces $\mathrm{Fe}_{2} \mathrm{O}_{3}$ which was also responsible for breaking down of bonding of mortars. Good quality of clay was used for mortar in the ancient period. $\mathrm{CaCO}_{3}$ has been found by XRD analysis. All these indicate that lime mortar was used as binding materials in the architecture of this site as well as medieval architecture of Shait Gambuz Mosque and the Residence of Khan Jahan. The absence of $\mathrm{CaCO}_{3}, \mathrm{Ca}$ and $\mathrm{CO}_{3}$ in the samples at Wari-Bateshwar, Lalmai-Mainamati and Paharpur 
indicates that clay was used as binding materials in the architecture. Higher amount of C has been found in all samples which indicates that more bio-organism or organic compound was used in the mortars. Large number of animals, birds and plants were found engraved on terracotta plaques. This indicates that there were a wide range of animals and plants at that time.

Cracks and pores are responsible for the deterioration of mortar strength in the joint areas of Buddhist Lotus Temple at Wari-Bateshwar. Stability of mortar was found well in Lalmai-Mainamati and Paharpur main temple leading to less damage of the architectural remains of these sites. The absence of $\mathrm{Ca}$ in the mortar samples indicate that clay mortar was used for the architecture at Wari-Bateshwar, Lalmai-Mainamati, and Paharpur. The ancient architecture of Wari-Bateshwar, Lalmai-Mainamati, and Paharpur were constructed with bricks where clay was used as mortars. $\mathrm{Na}$ and Fe can retain of moisture and water easily that can deteriorate of mortars faster. Oxidation of $\mathrm{Fe}^{+2}$ produced $\mathrm{Fe}_{2} \mathrm{O}_{3}$ which was responsible for breaking down the bonding of mortars.

\section{References}

Ahmed, N. 1975. Mahasthan, Dacca: p. 44-45.

Akasheh,T. S., B. M. Khrisat, M. N. Shaer and R. Sarayrsh. 2003-05. Archaeometric Investigation of Nabataean Mortars from Petra, "PRODOMEA Project: Project on High Compatibility Technologies and Systems for Conservation and Documentation of Masonry Works in Archaeological Sites of Mediterranean area, Wikipeadia 10-09-2012.

Alam, S. M. 2004. Two World Cultural Heritage Sites of Bangladesh, Department of Archaeology and UNESCO Dhaka, p. 1.

Ali, M. and M. S. Alam. 2000. Excavation at Rupban Mura Mainamati, Comilla, (Ahmed, N. Ed.), Department of Archaeology Department of Archaeology, Ministry of Cultural Affairs, Govt. of the Peoples Republic of Bangladesh, pp. 2-3.

Aziz, M. A. 1995. A Text Book of Engineering Materials, Z and Z Computers and Printers, Dhaka, pp. 103-114.

Brocken, H. J. P., M. E. Spiekman, L. Pel, K. Kopinga and J. A. Larbi. 2006. Wikipedia, the free encyclopedia 01-01-2012.

Candeias, A.E., P. Nogueira and J. Mirao, Silva, A. Santos. and Veiga, R. Casal, M. Gil., Ribeiro, I. and Seruya, A. I. Characterization of ancient mortar: Present methodology and future perspectives, Workshop on Chemistry in the conservation of Cultural Heritage: present and future perspective, Wikipeadia/12/09/2010

Dikshit, K. N. 1938. Memoirs of Archaeological Survey of India No. 55. Excavations at Paharpur, Delhi p. 141.

Ellis, P. 2002. The Analysis of Mortar, published online, Wikipeadia 05-10-2012.

Habesch, S. Material Research Institute of the Sheffield Hallam University, Wikipeadia/04/05/2010

Hossain,M. M. and M. A. Taher. 2007. Terracotta Plaques: A Panorama of Bangladesh Culture. Bangladesh quarterly, p. 73. 
Islam, A. M. 2005. Monument Preservation Activities in Bagerhat Undertaken in Recently Concluded Project, "Preservation of Monuments at Paharpur and Bagerhat", Past, Present and Future Plan of Bagerhat Shait Gumbaz Mosque, Khulna.

Jordan, B. 2006. Published online, Wikipeadia 12-09-2012.

Junzhe, L. 2008. Microscopy and Microanalysis of Mortar, Cambridge Univ. Press, Wikipeadia 0405-2012.

Khanom, M. A., 2007, An Investigation into the Deterioration and Conservation of Terracotta Plaques in Paharpur, M. Phill. Thesis, Dept. of Archaeology, Jahangingar University., Savar, Dhaka.

Khanom, M. A., 2012, Impact of Binding Materials and Media upon the Ancient Architecture of Bangladesh, Ph.D. Thesis, Dept. of Archaeology, Jahangingar University., Savar, Dhaka.

Masud, Alam A. K. M., Cheng Xie Shu, D. K. Sahs and S. Q. Chowdhury. 2008. Clay mineralogy of archaeological soil: An approach to palaeoclimate and environmental reconstruction of the archaeological sites of Paharpur area, Badalgacchi Upazila, Naogoan district, Bangladesh, Environmental Geology, 53. pp. 1639-1650.

Momber, A. W. 2002-03. An SEM-study of High-speed Hydrodynamic Erosion of Cementations Composites, published online, Wikipeadia 12-09-2012.

Patricia, A., T. Cruz, A. S. Silva, R. Veiga, A. Candeias and J. Mirao. 2008. Mineralogical Comparison Study of Old Mortars from Southern Portugal Cathedrals (Evora e Elvas), Published online, Wikipeadia 05-10-2012.

Petkovic, J. 2005. Published online, Wikipeadia 05-10-2012.

Rahman, S. S. M. 2001. Glass Beads from Wari-Bateshwar, Bangladesh: a Preliminary Study. Journal of Bengal Art (6): p. 201-209.

Rashid, M. H. 1997. Mainamati Devaparvata, (A.B.M Husain ed.), J. Asiatic Soc. of Bangladesh. pp. 2-68.

Rapp, G.R. 2002. 2003. 2009. Archaeomineralogy (Natural Science in Archaeology Series, Springer, Berlin Heidelberg New York, ISBN-3-540-42579-9, Uss89.95, Published Online, Wikipeadia/05/12/2010

Rapp, G, J. R. Rip and L. H. Christopher. 1930. Geo-archaeology, The Earth Science Approach to Archaeological Interpretation, Yale University Press, New Haven and London, p. 111132.

Rijniers, L. A. 2004. Published online, Wikipeadia/05/12/2010

Valckenborg, R. M. E., L. Pel, K. Hazrati, K. Kopinga and J. Marchand. 2001, 2006. Pore water distribution in mortar during drying as determined by NMR: Materials and Structures, Springer Netherlands, Wikipeadia 05-10-2012.

Válek, J., J. Hughes and P. Bartos. 1995. Gas Permeability, Porosity and Carbonation of Modern Conservation Lime Mortar Mix, Wikipeadia 05-10-2012.

Velosa, J. A. L., M. R. Coroado, P. Veiga and F. Rocha. 2007. Wikipeadia 05-10-2012 and 01-012012. 